\title{
Symptoms and Reason for a Medical Visit in Lung Cancer Patients
}

\author{
Sintomas e Motivo para uma Visita Médica em Doentes com Cancro do \\ Pulmão
}

Francisco-Javier GONZALEZ-BARCALA ${ }^{1}$, Jose-Antonio FALAGAN², Jose-Maria GARCIA-PRIM ${ }^{3}$, Luis VALDES ${ }^{1}$, JoseMartin CARREIRA ${ }^{4}$, Antonio POSE ${ }^{5}$, Juan-Carlos CANIVE ${ }^{6}$, Diana ANTON ${ }^{6}$, Maria-Teresa GARCIA-SANZ ${ }^{7}$, Amalia PUGA $^{8}$, Enrique TEMES ${ }^{9}$, Rafael LOPEZ-LOPEZ ${ }^{10}$

Acta Med Port 2014 May-Jun;27(3):318-324

\section{ABSTRACT}

Background: Patients with lung cancer usually present with symptoms at the time of diagnosis, but it is common that neither the doctor nor the patient initially associate them with the possibility of a malignant tumour.

Objectives: The aim of our study is to analyse the symptoms of patients with lung cancer and the relationship with the personal characteristics or the oncological disease.

Material and Methods: A retrospective study was conducted on all patients diagnosed with lung cancer in the Pontevedra Health Area over a period of three years. The symptoms presented by the patient, the reason for the consultation and the agreement between both or any factors associated with either of the two are analysed.

Results: A total of 358 patients, with a mean age of 68.7 years, and of whom $87 \%$ males, were included in the study. The most common initial symptoms were, constitutional in $30.4 \%$ of the cases, cough in $20.9 \%$ of cases, and in third place was chest pain, which was referred to by $12 \%$ of the patients. The most frequent reason for the consultation was dyspnea in $22.1 \%$ of patients, an incidental finding in $15.4 \%$, and haemoptysis in $12.8 \%$. There was a moderate association (correlation coefficient $=0.495$ ) between the initial symptoms and the consulting symptom.

Conclusions: A high percentage of patients with lung cancer had symptoms associated with the tumour at the time of diagnosis, even in early stage disease.

Keywords: Lung Neoplasms/diagnosis; Spain.

\section{RESUMO}

Contexto: A Os doentes com o diagnóstico de cancro do pulmão estão habitualmente sintomáticos no momento do diagnóstico, sendo comum que o médico ou o doente não associem essa sintomatologia com a eventualidade de um tumor maligno.

Objectivos: Este estudo teve como objectivo a análise dos sintomas de doentes com cancro do pulmão e sua relação com as características pessoais ou com a doença oncológica.

Material e Métodos: Foi levado a cabo um estudo retrospectivo englobando todos os doentes com o diagnóstico de cancro do pulmão na Região de Saúde de Pontevedra (Espanha) ao longo de um período de três anos. São analisados os sintomas de apresentação do doente, o motivo de consulta e a concordância entre ambos ou com quaisquer factores correlacionados.

Resultados: Foram incluídos no estudo 358 doentes, com uma média etária de 68,7 anos, sendo $87 \%$ dos doentes do sexo masculino. Os sintomas iniciais mais comuns foram sintomas constitucionais em $30,4 \%$ dos casos, tosse em $20,9 \%$ e dor torácica, descrita por $12 \%$ dos doentes. O motivo de consulta mais frequente foi dispneia em $22,1 \%$ dos doentes, um achado acidental em $15,4 \%$ dos doentes e hemoptise em 12,8\%. Observou-se uma associação moderada (coeficiente de correlação $=0,495$ ) entre os sintomas iniciais e o motivo de consulta.

Conclusões: Uma elevada percentagem de doentes com um diagnóstico de cancro do pulmão apresentou sintomas associados com o tumor no momento do diagnóstico, mesmo num estadio inicial da doença.

Palavras-chave: Neoplasias do pulmão/diagnóstico; Espanha.

\section{INTRODUCTION}

Lung cancer (LC) is usually diagnosed in the advance phases of its natural history, with the majority of patients, at the time of diagnosis, being in stages not amenable to surgical treatment, with the subsequent poor prognosis. ${ }^{1}$

A lung nodule can have grown considerably, even with spread outside the lung, before it may cause symptoms. ${ }^{1}$
The signs and symptoms of LC can be associated with the different characteristics of the disease, such as the growth of the primary tumour, intrathoracic or extrathoracic metastatic spread, paraneoplastic syndromes, or the constitutional effects of the cancer. ${ }^{2}$

The majority of patients with LC have symptoms when

1. Respiratory Department. Clinic University Hospital. Santiago de Compostela. Spain.

2. Clinical Documentation Department. Hospital of Pontevedra. Pontevedra. Spain

3. Thoracic Surgery Department. Clinic University Hospital. Santiago de Compostela. Spain.

4. Radiology Department. University of Santiago de Compostela. Santiago de Compostela. Spain.

5. Internal Medicine Department. Clinic University Hospital. Santiago de Compostela. Spain.

6. Family Medicine Department. Hospital of Pontevedra. Pontevedra. Spain.

7. Emergency Department. Hospital do Salnes. Pontevedra. Spain.

8. Nursery Department. University of Santiago de Compostela. Santiago de Compostela. Spain

9. Respiratory Department. Hospital of Pontevedra. Pontevedra. Spain.

10. Oncology Deparment. Clinic University Hospital. Santiago de Compostela. Spain

Recebido: 24 de Junho de 2013 - Aceite: 11 de Março de 2014 | Copyright (C) Ordem dos Médicos 2014 
they are diagnosed, but, given that the signs and symptoms of LC are common and unspecific, often in the context of other comorbidities like smoking, it is common that neither the patient nor the doctor associate them with the likelihood of tumour disease. ${ }^{3}$ Furthermore, LC symptoms are much more frequently associated with benign diseases. ${ }^{4}$

There also seems to be insufficient data on this population. In a study conducted on an Australian population, clinical signs and symptoms suggestive of LC were present, but less than one-third of this population recognised them as suggestive of LC, even in cases associated with smoking. ${ }^{5}$

An improved knowledge of the symptoms of LC would help in achieving a diagnosis in the less advanced phases of the disease.

Given that LC symptoms are frequently confused with other illnesses, they should be considered depending on the clinical epidemiological context, such as smoking history or changes in the characteristics of chronic symptoms. These clinical features are often nonspecific and insidious in their onset, and furthermore they are more usually attributable to benign causes often results in further delay in diagnosis.

The aim of our study is to analyse the symptomatology of patients with lung cancer, the reason for consulting, and the relationship of these with personal characteristics or the oncological disease.

\section{MATERIAL AND METHODS}

A retrospective, observational study was conducted that included all patients with a current diagnosis of LC in the Pontevedra Hospital Complex (CHOP) Health Area, an area that covers a population of 307916 inhabitants.

Patients diagnosed in the period of the study (between 1 June 2005 and 31 May 2008) were identified from the data provided by the Medical Records Department of the CHOP. Those patients with a histocytology confirmation of LC were included. Additionally, patients without a histocytology diagnosis were also included, if the clinical-radiological characteristics were compatible in conditions where other diagnoses were reasonably excluded. ${ }^{6}$

The variables recorded on each patient included, age, sex, smoking habits, comorbidity, functional state, diagnostic method, histology type, stage, treatment type, and survival.

To identify the initial symptom and the symptom prompting the consultation, in the doubtful cases, the history was reviewed by two of the authors who are specialists in pulmonology, internal medicine, oncology, thoracic surgery and radiology, identifying by consensus which symptom would be the initial one and which would be the symptom prompting the consultation.

The histological classification was carried out according to the World Health Organisation 1982 guidelines. ${ }^{7}$ The TMN tumour staging was performed based on that proposed by Mountain, ${ }^{8}$ which is accepted by the The Spanish Society of Chest Diseases and Thoracic Surgery (Sociedad Española de Neumología y Cirugía Torácica). ${ }^{9}$

Two groups were formed, based on age - younger or older than 70 years of age, the median age of our population. The study was approved by the Ethics Committee of Galicia.

\section{Statistical Analysis}

The categorical variables are expressed using frequencies and percentages.

The Chi-squared test was used for the comparison of the categorical variables.

The Cramer $\mathrm{V}$ statistic was used to analyse the correlation between variables.

A value of $p<0.05$ was considered significant.

The analysis was made using the SPSS 15.0 statistics package.

Table 1 - Main characteristics of study patients: descriptive data

\begin{tabular}{|c|c|}
\hline & $n(\%)$ \\
\hline \multicolumn{2}{|l|}{ Gender } \\
\hline Male & $313(87.4)$ \\
\hline Female & 45 (12.6) \\
\hline \multicolumn{2}{|l|}{ Age } \\
\hline$<50$ years-old & $21(5.9)$ \\
\hline $50-59$ years-old & 59 (16.5) \\
\hline $60-69$ years-old & $96(26.8)$ \\
\hline $70-79$ years-old & $121(33.8)$ \\
\hline$\geq 80$ years-old & $61(17.0)$ \\
\hline \multicolumn{2}{|l|}{ Smoking } \\
\hline Never smoker & $63(17.6)$ \\
\hline Former smoker & $155(43.3)$ \\
\hline Current smoker & $140(39.1)$ \\
\hline \multicolumn{2}{|l|}{ Charlson index } \\
\hline 0 & 89 (24.9) \\
\hline 1 & $100(27.9)$ \\
\hline 2 & $72(20.1)$ \\
\hline$\geq 3$ & $97(27.1)$ \\
\hline \multicolumn{2}{|l|}{ ECOG } \\
\hline 0 & $37(10.3)$ \\
\hline 1 & $197(55.0)$ \\
\hline 2 & $88(24.6)$ \\
\hline 3 & $24(6.7)$ \\
\hline 4 & $12(3.4)$ \\
\hline \multicolumn{2}{|l|}{ Histology type } \\
\hline Clinical radiological & $46(12.8)$ \\
\hline Small cell & $46(12.8)$ \\
\hline Squamous cell & $126(35.2)$ \\
\hline Adenocarcinoma & $85(23.7)$ \\
\hline Large cell & $14(3.9)$ \\
\hline Other & $51(11.6)$ \\
\hline \multicolumn{2}{|l|}{ TNM stage } \\
\hline I-A & $7(2.0)$ \\
\hline I-B & $25(7.0)$ \\
\hline II-A & $5(1.4)$ \\
\hline II-B & $4(1.1)$ \\
\hline III-A & $34(9.6)$ \\
\hline III-B & $105(29.5)$ \\
\hline IV & $176(49.2)$ \\
\hline
\end{tabular}


A total of 358 patients were finally included, $87 \%$ males, and with a mean age of 68.7 years, with $82 \%$ being smokers or ex-smokers (Table 1).

The most frequent initial symptom were constitutional symptoms in $29.9 \%$ of cases, followed by cough in $20.9 \%$ of cases, and in third place was chest pain, which was mentioned by $12 \%$ of the patients (Table $2 \mathrm{~A}$ ).

On analysing the symptoms that led to the patient consulting, the most frequent was dyspnea in $22.1 \%$ of them, followed by the incidental finding in $14.8 \%$, and haemoptysis in $12.8 \%$ (Table $2 \mathrm{~B}$ ).

The correlation between the initial symptom and the consulting symptom was moderate, with a correlation coefficient of 0.495 . When considering only those symptoms present in more than $5 \%$ of the patients, those that most frequently coincided with the consulting symptom were, haemoptysis (in $72.2 \%$ of cases), dyspnea in $64.3 \%$ of the patients, and neurological symptoms in $66.7 \%$ (Table 3 ).

No differences were seen in the initial symptom or the consulting symptom as regards the distribution by gender. Dyspnea was the most common consulting reason for both sexes. The most frequent initial symptom in males were constitutional symptoms, and in females it was cough (Data not shown).

There were no significant differences in the analysis by histology result or by stages, neither in the initial symptom nor in the symptom that led to the medical consultation (data not shown).

However, significant differences were observed depending on age, in both the first symptom and in the one that led to the medical consultation.

The most frequent initial symptom were constitutional symptoms in both age groups, but its incidence clearly increased with age (23\% of those under 70 years and $38 \%$ in the older group). The second most frequent symptom was cough $(22 \%$ in the younger group, and $20 \%$ in those over 70 years). Chest pain and neurological symptoms were much more frequent in the younger group $(p=0.000)$ (Table 4).

On analysing the consulting symptoms, $21 \%$ of the younger group consulted due dyspnea, and this was presented as an incidental finding in $16 \%$ of patients. The

Table 2A - Initial symptom

\begin{tabular}{lc}
\hline Symptom & $\boldsymbol{n}(\%)$ \\
\hline Constitutional syndrome & $107(29.9)$ \\
Cough & $75(20.9)$ \\
Thoracic pain & $43(12.0)$ \\
Respiratory infection & $24(6.7)$ \\
Neurologic symptoms & $24(6.7)$ \\
Musculoskeletal pain & $22(6.1)$ \\
Incidental & $21(5.9)$ \\
Hemoptysis & $18(5.0)$ \\
Dyspnea & $14(3.9)$ \\
Dysphonia & $7(2.0)$ \\
Other & $3(0.9)$ \\
\hline
\end{tabular}

most frequent consulting reason in the older group was still dyspnea (23\% of cases), but the second most frequent was haemoptysis, which led to the consultation in $16 \%$ of the patients $(p=0.010)$ (Table 5).

\section{DISCUSSION}

The symptomatology of cancer in general, and LC in particular, appears to be under-estimated in medical practice, as mentioned by some authors. ${ }^{10}$ Some likely causes are put forward, such as too much emphasis on population screening programs, nihilistic attitudes on the benefits of identifying these symptoms, or it is considered that the diagnosis requires complex complementary examinations, minimising the importance of the symptomatology. ${ }^{10}$

Even so, some authors have identified symptoms, such as dyspnea or haemoptysis, which are significantly associated with LC, especially in favourable epidemiological contexts, as would be long-term smoking, or the association with other symptoms common in patients with this type of tumour. 4 ,11-13

Other studies suggested that a greater awareness by the general population and family doctors of the signs and symptoms of LC could improve the prognosis of the disease, although the design of these studies does not allow definitive conclusions to be drawn on this. ${ }^{14,15}$

Constitutional symptoms, cough, and chest pain are the most common initial symptoms in our patients, which is similar to that in other populations, although there are some differences between the various series. ${ }^{1,4,16-21}$

In our study, only $5.9 \%$ of the patients were asymptomatic at the time of diagnosis, although there was an incidental diagnosis in $14.8 \%$ of cases, since although having symptoms associated with the tumour, these were not the reason for consulting. There is a wide variation between the different populations in the proportion of those diagnosed incidentally. Looking at countries like ours, it can vary between the $7 \%$ reported in Swedish or Italian studies, ${ }^{20,22}$ to up to $21 \%$ in an English population. ${ }^{22}$

However, the fact that the diagnosis of LC was incidental does not imply that the patient was asymptomatic, as shown in our study. In a Swedish study, that clearly differentiated between the symptoms of the patient and the consulting

Table 2B - Consulting symptom

\begin{tabular}{lc}
\hline Symptom & $\boldsymbol{n}(\%)$ \\
\hline Dyspnea & $79(22.1)$ \\
Incidental & $53(14.8)$ \\
Hemoptysis & $46(12.8)$ \\
Thoracic pain & $45(12.6)$ \\
Neurologic symptoms & $38(10.6)$ \\
Musculoskeletal pain & $26(7.3)$ \\
Constitutional syndrome & $25(7.0)$ \\
Cough & $12(3.4)$ \\
Respiratory infection & $10(2.8)$ \\
Dysphonia & $7(2.0)$ \\
Other & $16(4.7)$ \\
\hline
\end{tabular}




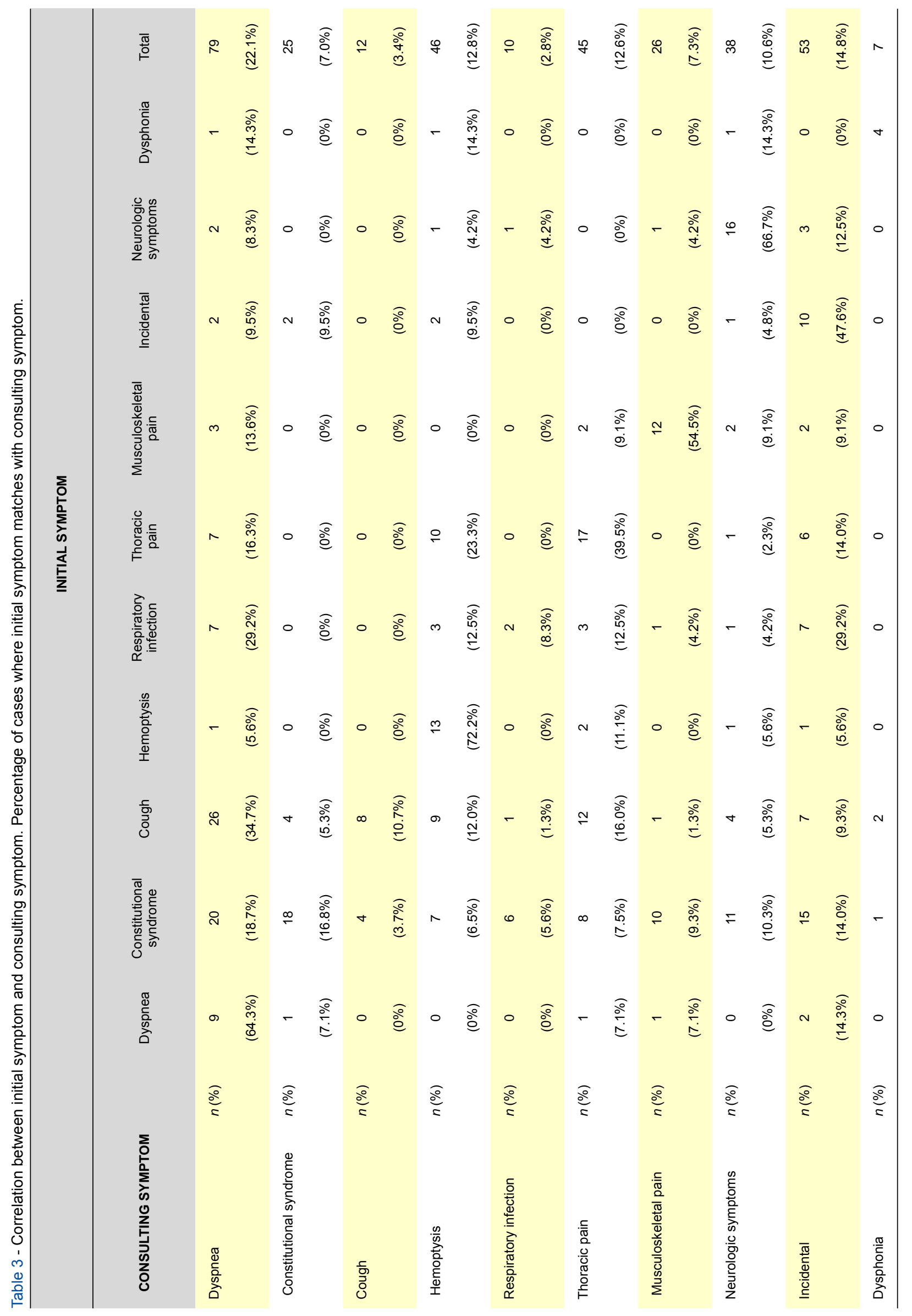


reason that led to the cancer diagnosis, $7 \%$ incidental diagnoses were reported, although almost $97 \%$ of the patients had symptoms associated with LC at the time of the diagnosis. ${ }^{20}$ Another recent Scottish study confirmed the elevated frequency of symptoms in these patients before the diagnosis, since $7 \%$ of them did not refer to symptoms, but on being presented with a list of possible symptoms associated with the disease, the majority of patients who where said to be asymptomatic recognised some symptom associated with LC, thus reducing the proportion of patients with no symptoms to $1 \% .^{18}$

Contrary to what would be expected, the presentation in the asymptomatic phase, like an incidental finding, is not significantly more frequent in the initial stages of LC. Even in non-small cell lung cancer (NSCLC) the incidental finding is slightly more frequent in extended disease than in limited disease. In fact, the 6 incidentally diagnosed cases of NSCLC were in stage III-B or IV (data not shown). However, other authors report differences in the symptoms by stages. In one study with a Danish population, a significant difference was observed between the symptomatology between stages, with the presentation as asymptomatic being most frequent in stage I (around 30\% of the cases) and haemoptysis in stage IV. ${ }^{23}$ In a study by Chen et al with a Texas-USA population, the proportion of incidental diagnoses was significantly lower in the earlier stages than in the advanced stages. ${ }^{24}$

No differences were observed in the symptomatology, either as regards the sex of the patient, or the tumour histology.

Contradictory findings are observed in the literature. In the Texas study, the epidermoid type was more frequently

Table 4 - Initial symptom, according to age ( $<70$ years-old $v s \geq 70$ years-old)

\begin{tabular}{lccc}
\hline \multicolumn{1}{c}{ Symptom } & $\begin{array}{c}<0 \text { years-old } \\
\boldsymbol{n}(\%)\end{array}$ & $\begin{array}{c}\mathbf{2} \text { (\% years-old } \\
\boldsymbol{n}(\%)\end{array}$ & $\begin{array}{c}\text { Total } \\
n(\%)\end{array}$ \\
\hline Constitutional syndrome & $40(37)$ & $67(63)$ & $107(29.9)$ \\
Cough & $39(52)$ & $36(48)$ & $75(20.9)$ \\
Thoracic pain & $28(65)$ & $15(35)$ & $43(12.0)$ \\
Respiratory infection & $6(25)$ & $18(75)$ & $24(6.7)$ \\
Neurologic symptoms & $18(75)$ & $6(25)$ & $24(6.7)$ \\
Musculoskeletal pain & $15(68)$ & $7(32)$ & $22(6.1)$ \\
Incidental & $13(62)$ & $8(38)$ & $21(5.9)$ \\
Hemoptysis & $9(50)$ & $9(50)$ & $18(5.0)$ \\
Dyspnea & $4(29)$ & $10(71)$ & $14(3.9)$ \\
Dysphonia & $6(86)$ & $1(14)$ & $7(2.0)$ \\
\hline
\end{tabular}

Table 5 - Consulting symtpom, according to age ( $<70$ years-old $v s \geq 70$ years-old)

\begin{tabular}{lccc}
\hline \multicolumn{1}{c}{ Symptom } & $\begin{array}{c}<0 \text { years-old } \\
\boldsymbol{n}(\%)\end{array}$ & $\begin{array}{c}\mathbf{7 0} \text { years-old } \\
\boldsymbol{n}(\%)\end{array}$ & $\begin{array}{c}\text { Total } \\
\boldsymbol{n}(\%)\end{array}$ \\
\hline Dyspnea & $38(48)$ & $41(52)$ & $79(22.1)$ \\
Incidental & $29(55)$ & $24(45)$ & $53(14.8)$ \\
Hemoptysis & $18(39)$ & $28(61)$ & $46(12.8)$ \\
Thoracic pain & $28(62)$ & $17(38)$ & $45(12.6)$ \\
Neurologic symptoms & $21(55)$ & $17(45)$ & $38(10.6)$ \\
Musculoskeletal pain & $10(38)$ & $16(62)$ & $26(7.3)$ \\
Constitutional syndrome & $7(48)$ & $18(52)$ & $25(7.0)$ \\
Cough & $9(75)$ & $3(25)$ & $12(3.4)$ \\
Respiratory infection & $2(20)$ & $8(80)$ & $10(2.8)$ \\
Dysphonia & $7(100)$ & $0(0)$ & $7(2.0)$ \\
\hline$p=0.010$ & &
\end{tabular}


presented as asymptomatic than an adenocarcinoma. ${ }^{24}$ On the other hand, in a recent Spanish study, the differences between the histology as regards the symptoms was significant, with epidermoid and adenocarcinoma being those that most frequently presented as an incidental finding. ${ }^{25}$

Discordant results have also been published as regards the association between gender and symptoms. In the study by Chen et al, as in our population, no differences were observed in the symptomatology between men and women, ${ }^{24}$ while in the study by Villamil et al there were significant differences, with haemoptysis being much more frequent in males, and dyspnea more frequent in females. ${ }^{25}$

Age may determine the different expression of symptoms, both in the start of the symptomatology and in the consulting symptom. In this respect, the published works agree with ours, showing significant differences between those less than 70 years and those of a more advanced age. ${ }^{24,25}$ In any case, the most frequent symptoms in each age group are different among the works published, since in our population the incidental finding was more frequent in the lower age population, while in the studies by Chen et al and Villamil et al the proportion of cases with an incidental diagnosis increased with age. ${ }^{24,25}$

On analysing the correlation between the initial symptom and the symptom that led to the patient consulting, it was observed that none of three most common coincided, with the overall correlation being moderate. Haemoptysis, dyspnea, and neurological symptoms were those that most often led to the medical consultation when they were the initial symptom of the patient. In our population, $72.2 \%$ of the patients who had haemoptysis as the first sign of a tumour ended up consulting for this reason, similar to that in other populations. ${ }^{20}$ On the other hand, when the initial symptom was cough or symptoms compatible with a respiratory infection, it was uncommon for the patient

\section{REFERENCES}

1. Spiro SG, Gould MK, Colice GL; American College of Chest Physicians Initial evaluation of the patient with lung cancer: symptoms, signs, laboratory tests, and paraneoplastic syndromes: ACCP evidencedbased clinical practice guidelines (2nd edition). Chest. 2007;132:S14960.

2. Navani N, Spiro SG. Symptoms and signs of lung cancer. Eur Respir Monogr. 2009;44:71-87.

3. Neal R, Muers M. Symptoms and assessment. In: Hunt I, Muers M, Treasure T, editors. ABC of Lung Cancer. Singapore: Ed- BMJ Books; 2009. Chapter 2. p. 6-10.

4. Hamilton W, Peters TJ, Round A, Sharp D. What are the clinical features of lung cancer before the diagnosis is made? A population based casecontrol study. Thorax. 2005;60:1059-65.

5. Jiwa M, Arnet H, Halkett G, Smith M, O'Connor M, Rhodes J, et al. Does smoking status affect the likelihood of consulting a doctor about respiratory symptoms? A pilot survey in Western Australia. BMC Fam Pract. 2009;10:16.

6. Prim JM, Barcala FJ, Esquete JP, Reino AP, López AF, Cuadrado LV. Lung cancer in a health area of Spain: incidence, characteristics and survival. Eur J Cancer Care. 2010;19:227-33.

7. World Health Organization. The World Health Organization histologycal typing of lung tumors. Second edition. Am J Clin Pathol. 1982;77:12336.

8. Mountain CF. Revisions in the internacional system for staging lung cancer. Chest. 1997;111:1710. to consult for these symptoms. In this sense, it is known that cough is the most common symptom in patients with LC, but it is also one of the most common symptoms for consulting in Primary Care, which could explain the lack of correlation between the start of the symptoms and the medical consultation. ${ }^{26}$

Our study may have certain limitations. First, as a retrospective study, certain symptoms may not be reflected very well in the medical history, which may imply a possible error in determination of the initial symptom or time of onset.

Secondly, the initial symptom and the symptom that led to the consultation could be confused with other chronic symptoms in habitual smokers. Review of medical records by a multidisciplinary group of health care specialists with care experience in these conditions should reduce potential bias in the identification of these symptoms.

\section{CONCLUSION}

In conclusion, our study appears to confirm that a high percentage of patients with LC have symptoms probably associated with a tumour at the time of diagnosis, even in the earliest stages of the disease. Neither the histological type nor the tumour stage appears to modify the expression of the symptoms. The relationship between the initial symptom of LC and the symptom that led to the consultation appears to be low, and could probably be increased by improving the health information to the public, and the awareness of Family Doctors on the importance of the symptoms in the early diagnosis of LC.

\section{CONFLICT OF INTERESTS}

The authors have no conflicts of interest.

\section{FUNDING SOURCES}

No subsidies or grants contributed to this work.

9. Rami Porta R, Duque Medina JL, Hernández Hernández JR, López Encuentra A, Sánchez de Cos Escuin J. Normativa actualizada (1998) sobre el diagnóstico y estadificación del carcinoma broncogénico. Recomendaciones SEPAR. Arch Bronconeumol. 1998;34:437-52.

10. Hamilton W. Five misconceptions in cancer diagnosis. $\mathrm{Br} \mathrm{J}$ Gen Pract. 2009;59:441-7.

11. Thirumaran $M$, Sundar $R$, Sutcliffe IM, Currie DC. Is investigation of patients with haemoptysis and normal chest radiograph justified? Thorax. 2009;64:854-6

12. Hamilton W. Cancer diagnosis in primary care. $\mathrm{Br} \mathrm{J}$ Gen Pract. 2010;60:121-8

13. Hippisley-Cox J, Coupland C. Identifying patients with suspected lung cancer in primary care: derivation and validation of an algorithm. $\mathrm{Br} J$ Gen Pract. 2011;61:e715-23.

14. Simon AE, Juszczyk D, Smyth N, Power E, Hiom S, Peake MD, et al. Knowledge of lung cancer symptoms and risk factors in the U.K.: development of a measure and results from a population-based survey. Thorax. 2012;67:426-32.

15. Athey VL, Suckling RJ, Tod AM, Walters SJ, Rogers TK. Early diagnosis of lung cancer: evaluation of a community-based social marketing intervention. Thorax. 2012;67:412-7.

16. Jiménez Massa AE, Alonso Sardón M, Gómez Gómez FP. Cáncer de pulmón: ¿cómo se presenta en nuestra consulta? Rev Clin Esp. 2009;209:110-7.

17. Corner J, Hopkinson J, Fitzsimmons D, Barclay S, Muers M. Is late 
diagnosis of lung cancer inevitable? Interview study of patients recollections of symptoms before diagnosis. Thorax. 2005;60:314-9.

18. Smith SM, Campbell NC, MacLeod U, Lee AJ, Raja A, Wyke S, et al. Factors contributing to the time taken to consult with symptoms of lung cancer: a cross-sectional study. Thorax. 2009;64:523-31.

19. Buccheri G, Ferrigno D. Lung cancer: clinical presentation and specialist referral time. Eur Respir J. 2004;24:898-904.

20. Lövgren $M$, Leveälahti $H$, Tishelman $C$, Runesdotter $S$, Hamberg $K$. Time spans from first symptom to treatment in patients with lung cancer-the influence of symptoms and demographic characteristics. Acta Oncol. 2008;47:397-405.

21. Ellis PM, Vandermeer R. Delays in the diagnosis of lung cancer. J Thorac Dis. 2011;3:183-8.

22. Imperatori A, Harrison RN, Leitch DN, Rovera F, Lepore G, Dionigi G, et al. Lung cancer in Teesside (UK) and Varese (Italy): a comparison of management and survival. Thorax. 2006;61:232-9.

23. Christensen ED, Harvald T, Jendresen M, Aggestrup S, Petterson G. The impact of delayed diagnosis of lung cancer on the stage at the time of operation. Eur J Cardiothorac Surg. 1997;12:880-4.

24. Chen X, Gorlov IP, Ying J, Merriman KW, Kimmel M, Lu C, et al. Initial medical attention on patients with early-stage non-small cell lung cancer. PLoS One. 2012;7:e32644.

25. Villamil Cajoto I, García Prim JM, González Barcala FJ, Pose Reino A, Paredes Vila S, Calvo Alvarez U, et al. Motivo de consulta en el diagnóstico de cáncer de pulmón. Revisión de 481 casos. Rev Clin Esp. 2009;209:67-72.

26. Simpson CB, Amin MR. Chronic cough: state-of-the-art review. Otolaryngol Head Neck Surg. 2006;134:693-700. 
Francisco-Javier GONZALEZ-BARCALA, Jose-Antonio FALAGAN, Jose-Maria GARCIA-PRIM, Luis VALDES, Jose-Martin CARREIRA, Antonio POSE, Juan-Carlos CANIVE, Diana ANTON, Maria-Teresa GARCIA-SANZ, Amalia PUGA, Enrique TEMES, Rafael LOPEZ-LOPEZ

\section{Symptoms and Reason for a Medical Visit in Lung Cancer Patients \\ Acta Med Port 2014:27:318-324}

Publicado pela Acta Médica Portuguesa, a Revista Científica da Ordem dos Médicos

Av. Almirante Gago Coutinho, 151

1749-084 Lisboa, Portugal.

Tel: +351218428215

E-mail: submissao@actamedicaportuguesa.com

www.actamedicaportuguesa.com

ISSN:0870-399X | e-ISSN: 1646-0758

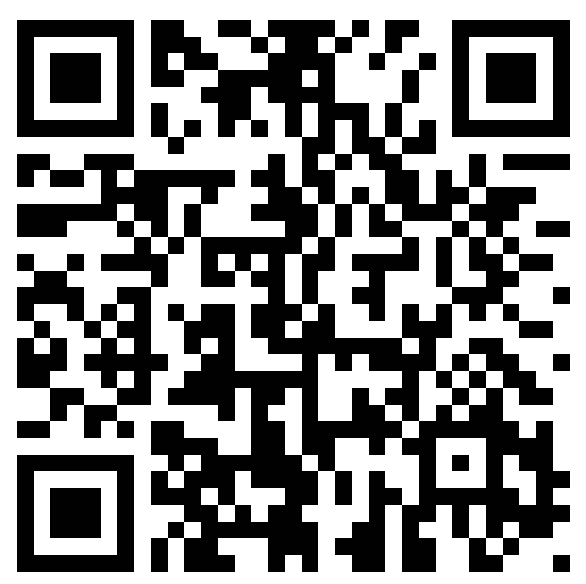

